\title{
The Influence of Hand Washing Behaviour on Diarrhea Case in Pre-School Students of Ra Al-Aziziyah Mataram in 2019
}

\author{
Indah Puspa Komalasari \\ Master of Public Health Program, Faculty of Public Health, University Of Muhammadiyah Jakarta \\ K.H Ahmad Dahlan St, Cireundeu, Ciputat, South Jkarta, Banten 15419 \\ E-mail:
}

\begin{abstract}
The handwashing behavior is an activity conducted by a person to clean the palm for removing microorganisms. Unclean Palm Will Likely Increase The Risk Of Diarrhea Cases. The influence of handwashing on diarrhea in pre-school students of RA Al-Aziziyah Mataram in 2019. The research design used in this study is Cross-Sectional. The sample of this research is 60 pre-school students in which the sampling technique used is purposive sampling. This research was conducted on $15-21$ of March 2019. The instrument in collecting the data is a questionnaire. Furthermore, the data were analyzed by using the chi-square test. Based on the research result, it is found that the sing value (2tailed) is $0.01 \rightarrow$ It Should Be $<0,05$. There is a significant influence of handwashing behavior on diarrhea cases in pre-school students of Quran Al-Aziziyah Mataram 2019. A recommendation that can be conferred to parents is that they have to teach their children to maintain handwashing behavior competently that is appropriate with the seven steps and use soap to decrease diarrhea cases on children.
\end{abstract}

Keywords: behavior, hand washing, diarrhea case 


\section{INTRODUCTION}

Pre-school students that are in the Golden Age are those who are $3-5$ years old. The preschool stage is also a cognitive stage in which the children start showing growth and they have prepared themselves to enter school. Learning abilities that are needed by the pre-school students include recognizing color, numbers, and letters, counting simply, understanding the adjective, and recognizing the shape of a certain object (Utami, 2009).

Self-cleanliness comprises the cleanliness of the body, such as wearing clean clothes, taking a bath, brushing teeth, and washing hands (Susanto, 2011). The behavior of handwashing is an activity conducted by a person to clean palm, backhand, and fingers to be clean from the dirt and lethal germ that cause disease that endangers human's health such as diarrhea (Nadesul, 2009).

World Health Organization (WHO) states that one hundred thousand Indonesian children die caused by diarrhea. The data that was released by Riskedas in 2007 suggested that diarrhea is one of the two most death causes in children, besides pneumonia. The death of $4-11$-year-old children caused by diarrhea is $25,5 \%$ and pneumonia is $15,5 \% .40-60 \%$ of diarrhea in children is caused by rotavirus. This virus generally enters the mouth through a hand that is contaminated by dirt as a result of not washing hands (Riskesdas, 2007).

The number of diarrhea cases is approximately $200-400$ out of 1.000 Indonesian citizens every year. Most of the cases $(70-80 \%)$ occur in 5 -year-old children ( \pm 40 million cases). This group, every year, suffers from more than one diarrhea occurrence. Some of these sufferers (12\%) will get dehydrated and if it is not handled immediately, $50-60 \%$ of them can die (Sudaryat, 2010). The number of diarrhea cases in West Nusa Tenggara in 2017 reaches 89.869 cases in which the proportion of children under 5 years old is $39,49 \%$. These cases increase in 2016 in which the cases found are 1.063.949 where 37,94 among them are children under five (West Nusa Tenggara Province Health Department, 2018).

Based on the research conducted by Rafri Aditya Purnomo (2013) entitled: The Influence of Hand Washing Behaviour on Pre-school Students of PAUD Desa Kalikotes Klaten", in which the test analysis result used t-test, the p-value is 0,003 with the level of significance $(0,05)$, since the value of $0,003<0,05$, thus, this can be concluded that there is an influence of handwashing behavior on diarrhea case in the pre-school students of PAUD Kalikotes Klaten Village.

Based on the preliminary study result in RA Quran Al-Aziziyah Kapek Gunungsari in September 2018 in which 5 mothers were interviewed, 3 mothers stated that their children infrequently wash their hands before eating, therefore, within 3 months, they suffer from diarrhea. Meanwhile, two mothers said that their children frequently wash their hands before eating, but they still suffer from diarrhea. Those mothers argued that diarrhea cases in their children could be affected by the hygiene of the snacks that are bought in the stall. 
Based on the explanation of the background above, the researcher is interested to research:

"The Influence of Hand Washing Behaviour on the Diarrhea Case in Pre-school Students of RA Quran Al-Aziziyah”.

\section{METHODS}

The research design employed in this research is cross-sectional in which every subject of this research is only observed once and the measurement on the variable is conducted at the same time (Notoatmodjo, 2010).

\section{RESULTS AND DISCUSSIONS}

Based on the table below, it can be concluded that most of the respondents' age is 6 years old which contribute to 33 students $(55,0 \%)$

Table 1. The Distribution of Respondents' Characteristics based on the age of Preschool Students in RA Quran Al-Aziziyah in 2019.

\begin{tabular}{lccc}
\hline & Students' Age & N & Percentage (\%) \\
\hline 5 years old & 27 & $45,0 \%$ \\
6 years old & 33 & 55,0 \\
Total & 60 & $100 \%$ \\
\hline
\end{tabular}

Source: Primary Data 2019

From table 2, it can be concluded that most of the students' sex is male which contributes to 42 students $(70,0 \%)$

Table 2. The Distribution Frequency of Respondents based on the pre-school students' sex in RA Quran Al-Aziziyah Mataram in 2019.

\begin{tabular}{lcc}
\hline \multicolumn{1}{c}{ Students' sex } & N & Percentage (\%) \\
\hline Male & 18 & $30,0 \%$ \\
Female & 42 & $70,0 \%$ \\
Total & 60 & $100 \%$ \\
\hline
\end{tabular}

Source: Primary Data 2019

From table 3, it can be inferred that most of the parents' education background is SDN/Elementary School which contributes 34 parents $(56,7 \%)$.

Table 3. Distribution Frequency of Respondents based on the students' parents' education background in RA Quran Al-Aziziyah Mataram in 2019.

\begin{tabular}{lcc}
\hline \multicolumn{1}{c}{ Parents Education } & N & Percentage (\%) \\
\hline SDN & 34 & $56,7 \%$ \\
SMP & 6 & $10,0 \%$ \\
SMA & 14 & $23,3 \%$ \\
D3 & 4 & $6,7 \%$ \\
S1 & 2 & $3,3 \%$ \\
Total & 60 & $100 \%$ \\
\hline
\end{tabular}

Source: Primary Data 2019 
From the table above, it can be inferred that most of the students' parents' profession is seller which contributes 31 parents $(51,7 \%)$.

Table 4. Distribution Frequency of Respondents based on the students' parents' profession of RA Quran Al-Aziziyah Mataram in 2019.

\begin{tabular}{lcc}
\hline \multicolumn{1}{c}{ Parents Profession } & N & Percentage(\%) \\
\hline Housewife & 16 & $26,7 \%$ \\
Farmer & 3 & $5,0 \%$ \\
Seller & 31 & $51,7 \%$ \\
Private Employee & 4 & $6,7 \%$ \\
Police & 1 & $1,7 \%$ \\
Civil Servant & 1 & $1,7 \%$ \\
Teacher & 4 & $6,7 \%$ \\
Total & 60 & $100 \%$ \\
\hline
\end{tabular}

Source: Primary Data 2019

From table 5, it can be concluded that most of the respondents' handwashing behavior is good which represents 41 people $(68,3 \%)$

Table 5. The respondent's distribution is based on the handwashing behavior of preschool students of RA Quran Al-Aziziyah Mataram in 2019.

\begin{tabular}{lcc}
\hline \multicolumn{1}{c}{ Hand Washing Behaviour } & N & Percentage(\%) \\
\hline Good Enough & 41 & $68,3 \%$ \\
Lack & 4 & $6,7 \%$ \\
Total & 60 & $100 \%$ \\
\hline
\end{tabular}

Source: Primary Data 2019

Based on table 6 , it is inferred that, from the 60 respondents, there is no diarrhea case in 32 students $(53,3 \%)$.

Table 6. The distribution is based on the respondents with the diarrhea case on preschool students of Ra Quran Al-Aziziyah Mataram in 2019.

\begin{tabular}{ccc}
\hline Diarrhea Case & N & Percentage(\%) \\
\hline No & 32 & $53,3 \%$ \\
Yes & 28 & 46,7 \\
Total & 60 & $100 \%$ \\
\hline
\end{tabular}

Source: Primary Data 2019

The statistical test result of chi-square shows that the p-value is 0.01 or $p 0.05$. Ho is denied and $\mathrm{Ha}$ is accepted which suggests that there is an influence of handwashing behavior on diarrhea cases in pre-school students of RA Quran Al-Aziziyah Mataram in 2019.

Based on table 7 below, it is shown that, out of 60 respondents who have good handwashing behavior, 26 respondents $(43,3 \%)$ do not suffer from diarrhea cases and 15 respondents $(25,0 \%)$ suffer from it. 
Table 7. The influence of handwashing behavior on diarrhea case in pre-school students of Ra Quran AlAziziyah Mataram in 2019.

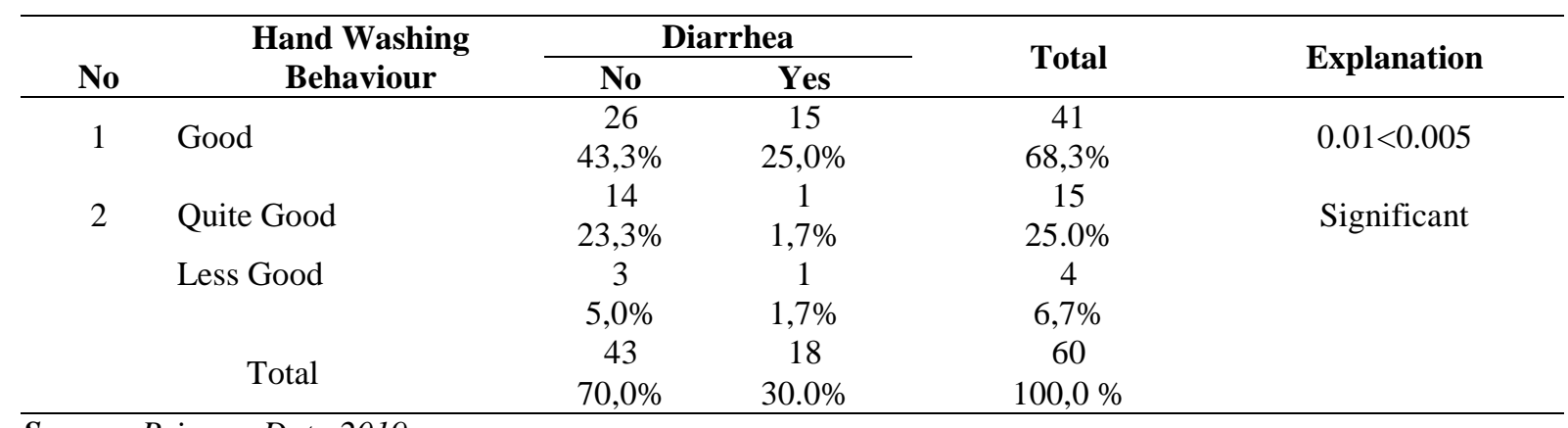

Source: Primary Data 2019

Based on the research result, it is found that most of the respondents have good handwashing behavior which represents 41 people $(68,3 \%)$. Moreover, the lowest rate of handwashing behavior is less than 4 respondents $(6,7 \%)$.

According to Nadesul (2006), handwashing behavior is an activity conducted by a person in cleaning the palm and fingers so that it is clean from any dirt and germ that cause disease which affects human health. Furthermore, Rachmayanti (2013) stated that there are many infectious diseases caused by the lack of clean living behavior, for instance, washing hands. There have been many proofs that show that handwashing behavior by using water and soap can decrease the case and spreading various infectious diseases. By washing hands with water and soap, effectively removes the dirt and dust from the skin surface and decreases the number of microorganisms that cause diseases such as viruses, bacteria, and parasites on both hands instead of washing hands only with water. Therefore, washing hands with water and soap can clean the dirt and germ that are hidden and stuck on the skin surface, nails, and fingers of both hands more effectively.

Based on the interview result conducted by the researcher during the research following the questionnaire items, the average of parents stated that their children always wash their hands before eating with flowing water and they always wash their hands after taking a dump as well. Besides that, the teachers also teach and explain how to wash hands appropriately using soap with the seven steps of washing hands. Meanwhile, labeled as quite good, from the interview result, 15 respondents $(25,0 \%)$ rarely wash their hands with soap and flowing water and they also incompetently do it with the seven steps of washing hands. Furthermore, obtained from the interview, the respondents that have poor handwashing behavior are only 4 people $(6,7 \%)$. The factors that cause the children do not to want to wash their hands is because they are lazy and do not have that kind of habitual act. In addition, they often do various activities without washing hand with soap.

From the research result, it shows that from 60 respondents who have good handwashing behavior, 26 respondents $(43,3 \%)$ do not suffer from diarrhea and 15 respondents $(25,0 \%)$ suffer from 
diarrhea. Based on the data above, it can be concluded that handwashing behavior is very important to prevent diseases that cause diarrhea.

Based on table 3 above, it can be concluded that from the highest 60 respondents, there are 32 people $(53,3 \%)$ who do not suffer from diarrhea. And the lowest rate, there are 28 people $(46,7 \%)$ who suffer from diarrhea.

Based on the result of the research that has been conducted by the researcher during the research following the questionnaire, the average of parents stated that their children take a dump more than three times a day accompanied by nausea and vomiting, do not want to eat, and drink, are fussy and cry, look wrinkled and weak on their skin and face. When suffering diarrhea, children tend to have a stomachache and the factors of those symptoms are said as their children rarely wash their hands with soap and eat inappropriate snacks/meals.

Diarrhea is a disease marked by the increase of defecation frequency more than usual (> 3 times a day) accompanied by the change of feces consistency (become liquid), with or without blood or mucous (Suraatmaja, 2007). The factors that cause diarrhea are the habit of not giving breast milk exclusively, providing complementary food for the infants too early that advances the risk to contact with germ, using milk bottle proved to increase the risk of suffering diarrhea as it is difficult to clean the milk bottle, the absence of hand washing habit implementation with soap before breastfeeding/feeding the children and after taking a dump (Marjuki, 2008). The spread of diarrhea is caused by the infection from a causative agent that will occur if one consumes food or drink that is contaminated by the feces of diarrhea patient. The purpose of washing hands is to prevent infection spread since the disease spread can occur if someone that is affected does not wash hands appropriately and immediately touch or cook food that will be consumed by others. Handwashing behavior with soap appropriately and at the right time is crucial in controlling the diarrhea case in children.

Statistical test result with chi-square obtained that $\mathrm{p}$-value 0.01 or $\mathrm{p} 0.05$. Ho is denied and $\mathrm{Ha}$ is accepted which means that there is an influence of handwashing behavior on diarrhea cases in preschool students of RA Quran Al-Aziziyah Mataram in 2019. Based on table 5.4 above, it is shown that, out of 60 respondents who have good handwashing behavior, 26 respondents $(43,3 \%)$ do not suffer diarrhea and 15 respondents $(25,0 \%)$ suffer from it.

Based on table 2 above, it can be concluded that most of the respondents have good handwashing behavior which represents 41 people $(68,3 \%)$. While the number of respondents who have poor handwashing behavior is 4 people $(6,7 \%)$.

Furthermore, based on table 3 above, it is found that, out of 60 respondents in RA Quran AlAziziyah Mataram in 2019, 32 people (53,3\%) do not suffer from diarrhea and 28 people (46,7\%) suffer from it. 
According to Health Department (2011), washing hands with clean water can remove the diarrheal germ. Diarrhea is frequently associated with the water condition, but accurately, what must also be aware of is the handling of human waste such as feces and urine since the bacterial germs that cause diarrhea are from these wastes. These bacterial germs make humans sick if they get into the mouth through the hand that nudges feces, contaminated water, raw food, and cooking tools that have never been washed before used or contaminated by dirty cooking tools. Thus, hand washing becomes intensely important to avoid diseases such as diarrhea.

This research result agrees with the research result by Rosyidah (2014) which entitled The Relation Between Hand Washing Behaviour and Diarrhea Case on Students in SDN, South Tangerang, Banten, that shows there is a significant correlation between handwashing behavior with diarrhea case.

\section{CONCLUSIONS AND SUGGESTIONS}

The research result found that there is handwashing behavior on Pre-school Children in RA Qur'an Al-Aziziyah. Most of the respondents have good handwashing behavior which represents 41 people $(68,3 \%)$.

The result of the study suggested that there has been diarrhea case on Pre-school students in RA Qur'an Al-Aziziyah in which 26 respondents $(43,3 \%)$ do not suffer from diarrhea.

From the statistical test result using chi-square, the influence of handwashing behavior on diarrhea cases is 0.05 which suggests that there is an influence of handwashing behavior on diarrhea cases in Pre-school Children of RA Qur'an Al-Aziziyah in 2019.

A billion thanks uttered to Dian Istiana, Ners,Sp.kep. Jiwa. as the first supervisor that has devoted and guided me patiently. Fitri Rhomadhonika S.Kep.,Ns.,M.Kep is the second supervisor that has given so much love and patience in guiding me during the research. Dr. Dewi Purnamawati, S.KM, M.KM. as the lecturer of Research Methodology subject of Master of Public Health Program, Faculty of the Public Health University of Muhammadiyah Jakarta that has given the chance and support to our group in arranging this manuscript.

\section{REFERENCES}

Darmiatun. 2013. Implementasi Pendidikan Karakter di Sekolah. Yogyakarta : Gava Media.

Dinas Kesehatan Provinsi NTB, 2018. Angka Kejadian Diare. Mataram : NTB.

Depkes, RI. 2010. Panduan Perilaku Hidup Bersih Dan Sehat Di Rumah Tangga. Pusat Promosi Kesehatan, Jakarta

Notoatmodjo, S. 2010. Metodologi Penelitian Kesehatan. Jakarta : Rineka Cipta

Proverawati, Eni Rahmawati. 2012. Perilaku hidup bersih dan sehat. (PHBS). Yogyakarta: Nuha Medika 
E-ISSN: 2808-5361

http://e-journal.fkmumj.ac.id/
Proceeding The First Muhammadiyah InternasionalPublic Health and Medicine Conference

Rafri Aditya Purnomo, 2013. "Pengaruh Perilaku Mencuci Tangan Terhadap Kejadian Diare Pada Anak Usia Prasekolah di PAUD Desa Kalikotes Klaten.

Riskesdas, 2007. Riset Kesehatan Dasar. Jakarta : Badan Penelitian dan. Pengembangan Kesehatan, Departemen Kesehatan, Republik Indonesia.

Sax, H., et al. 2007. My Five Moment For Hand Hygiene: A user Centred Design Approach to Understand Train Monitor and Report Hand Hygiene. Journal of Hospital Infection, 67, 9-21.

Siswanto, 2010. Pendidikan Kesehatan Anak Usia Dini. Yogyakarta : Pustaka Rihama.

Schaffer. 2010. Pencegahan Infeksi Dan Praktek Yang Aman. Jakarta: EGC

Soedarmo, et al. 2008. Buku Ajar Infeksi dan pediatri topis. Jakarta : Badan Penerbit IDAI.

Sudaryat S. 2010. Gastroenterologi. Anak Lab/SMF Ilmu Kesehatan Anak Fakultas UNUD.

Suraatmaja, 2007. Kapita Selekta Gastroenterologi. Jakarta : Sagung Seto.

Susiati, 2008. Keterampilan Keperawatan Dasar, Paket 1. Jakarta : Erlangga Medical Series.

Umar, 2009. Kebiasaan Mencuci Tangan Dengan Infeksi Pada Anak SDN 34 Pekalongan, Jawa Tengah. Makara Kesehatan 